\title{
ROLE OF VIRECHANA KARMA (THERAPEUTIC PURGATION) IN PSORIASIS: A CLINICAL STUDY
}

\section{Auyrveda}

Mishra Meenu*

Post Graduate Scholar Kayachikitsa,Pt. Khushilal Sharma Govt.(Auto.) Ayurveda College and Institute, Bhopal, Madhya Pradesh, India. * Corresponding Author

Sharma Ankita Post Graduate Scholar Rasashastra, Pt. Khushilal Sharma Govt.(Auto.) Ayurveda College and Institute, Bhopal, Madhya Pradesh, India.

Shivhare Shwetal

Reader Department of Kayachikitsa, Pt. Khushilal Sharma Govt.(Auto.) Ayurveda College and Institute, Bhopal, Madhya Pradesh, India.

SharmaVivek

Lecturer Department of Kayachikitsa, Pt. Khushilal Sharma Govt.(Auto.) Ayurveda College and Institute, Bhopal, Madhya Pradesh, India.

\section{ABSTRACT}

Background: The skin or the integument is the external organ that protects against mechanical trauma, UV light and infections. The prevalence of skin diseases in India is 10 to $12 \%$ of the total population with psoriasis being the major contributor, in India it ranges from $0.44 \%$ to $2.8 \%$. In Ayurveda all skin diseases come under the concept of Kushta. Psoriasis has a high resemblance with Ekkushta, which is the type of Kshudrakushta (less severe form of the Kushta). Skin diseases considered as Pitta Doshaja and Rakta Dhatu Pradoshaja Vikara. Acharya Charaka stated that Virechana is the great treatment for Pitta predominance diseases. Aim: To study the role of Virechana Karma in the management of Ekkushta (Psoriasis). Material and Methods: A single group of 5 diagnosed patients of Ekkushta (Psoriasis) were registered at the Kayachikitsa OPD of Pt. Khushilal Sharma Govt. (Auto.) Ayurvede Hospital Bhopal. The patients were treated with Virechana Karma. Duration of study is 21 days and follow up after completion of trial every week for 1 month. Assessment was done on the basis of symptomatic relief after treatment. Observation: The overall effect of the Virechana Karma in all patients suggested that, complete cure was not in any patient. One patient was mild improved, one patient was markedly improved and three patients were moderately improved. None of patients remained unchanged. Conclusion: On the basis of this clinical trial it can be concluded that Virechana Karma works effectively in the management of psoriasis.

\section{KEYWORDS}

\author{
Psoriasis, Ekkushta, Virechana Karma
}

\section{INTRODUCTION}

Diseases affecting the skin are common and important because absence of normal skin function, can severely impair quality of life. This may be exacerbated by the fact that people with skin disease can suffer the effects of stigma, particularly as regards visually disfiguring skin changes or the belief that they are contagious. Skin diseases affect all ages and there are more than 2000 different types and presentations. Psoriasis is a chronic inflammatory, hyperproliferative skin disease. It is characterized by well-defined, erythematous scaly plaques, particularly affecting extensor surfaces, scalp and nails and usually follows a relapsing and remitting course. Psoriasis affects approximately $1.5-3 \%$ of Caucasians but is less common in Asians, South American and African populations. It occurs equally in both sexes and at any age; although it is uncommon under the age of 5 years, more than $50 \%$ of patients present before the age of 30 years. ${ }^{1}$ The underlying cause of psoriasis is thought to be our immune system unnecessarily accelerating the growth of skin cells resulting in inflammation. Ayurvedic literature has described skin diseases mainly under the spectrum of Kushta. According to Ayurveda, psoriasis compare to Ekkusthha occur due to vitiation of Vata, Pitta, Kapha and Rakta Doshas (body humors). Ekkushta (psoriasis) is one of the varieties of eleven Kșhudrakuștha (comparatively less harmful, easily treated obstinate diseases of skin). The clinical features are Mahavastu (widespread lesions), Aswedanam (lack of perspiration) and Matsyashaklopmam (fish scale like appearance). ${ }^{2}$ In Kushta, Shodhana Chikitsa (bio-purification) should be carried out repeatedly to prevent recurrence. ${ }^{3}$ Management of psoriasis as per contemporary treatment modalities include use of steroids and other therapeutics which only suppress the symptoms and having long term side effects. This shows that need of search of some alternative treatment is highly desirable. This paper highlights the role of Virechana Karma (Therapeutic purgation) in psoriasis.

\section{MATERIALAND METHODS}

A single group of 5 diagnosed cases of Ekkushta (Psoriasis) were registered from OPD of Kayachikitsa department and admitted in IPD of Pt. Khushilal Govt. (Auto.) Ayurveda Hospital Bhopal. Patients were selected randomly and placed into one group i.e. Trial or Experimental group. Consent was taken from all the patients.

The drugs required for Virechana Karma procured and prepared in Prakalp of Panchkarma in Pt. KLS Govt. Ayurveda Hospital Bhopal.

These registered patients were properly informed regarding the Virechana procedure, they would undergo and admitted in the hospital indoor ward and treated under direct supervision.

Duration of study: 21 days and follow up after completion of trial every week for 1 month

\section{TREATMENT REGIMEN}

These diagnosed cases of Ekkushta (Psoriasis) admitted in indoor ward of Pt. K. L. S. Govt. Ayurveda Hospital, Bhopal and undergo following procedures:-

\section{Table No.-1}

\begin{tabular}{|c|l|l|l|l|}
\hline $\begin{array}{l}\text { S. } \\
\text { No. }\end{array}$ & TREATMENT & DOSE & FREQUENCY & $\begin{array}{l}\text { DURATI } \\
\text { ON }\end{array}$ \\
\hline 1. & Deepan-Pachan with & & & 3 days \\
\hline & Chitrakadi Vati & $2 \mathrm{tab}$ & q.i.d. & \\
\hline & Panchkol Phanta & $20 \mathrm{ml}$ & Every 2 hourly & \\
\hline 2. & Snehapana with & $30 \mathrm{ml}$ to & Orally, empty & 7 days \\
\hline & $\begin{array}{l}\text { Panchtiktaghrita } \text { start } \\
\text { with }\end{array}$ & $350 \mathrm{ml}$ & Stomach, once & \\
\hline & $30 \mathrm{ml}$ in increasing dose & & in a morning & \\
\hline & till Samyak Snehana & & & \\
\hline & Lakshana obtained & & & 3 days \\
\hline 3. & Sarvang Abhayang with & Q.S. & Once in a & \\
\hline & Narayan oil and Nadi & & Morning & \\
\hline & Swedana with Dasmool & & & \\
\hline & Kwath & & & 1 day \\
\hline 4. & Virechana Karma with & & & \\
\hline & Trivattadi Kwath* & $200 \mathrm{ml}$ & Once in a & \\
\hline & Ichhabhedi Rasa & $250 \mathrm{mg}$ & Morning & \\
\hline & & & hours empty & \\
\hline & & & Stomach & \\
\hline 5. & Samsansarjana Karma & - & - & \\
\hline & (Diet control) & - & - & \\
\hline
\end{tabular}

Trivattadi Kwath* contents- Aragvadha(Cassia fistula), Draksha (Vitis vinifera), Kutki (Picrorhiza kurroa), Trivatta/Nishoth (Operculina terpethum), Baal Haritaki (Terminalia chebula) each had taken in $20 \mathrm{mg}$ quantity. 
INCLUSION CRITERIA

- Patients presenting with classical and modern clinical features of Ekkushta (psoriasis)

\section{EXCLUSION CRITERIA}

- Patients of Eczema and Leprosy.

\section{CRITERIA FOR EXAMINATION AND DIAGNOSIS ${ }^{4}$}

The diagnosis will be made on the basis of the following clinical findings.

1. Typical distribution of the Psoriatic lesions on the surface of the body such as elbow, knee, lower back, scalp, nails etc.

2. Well defined non-indurated, dry erythematous area with silvery layer scaling.

3. The candle grease sign, kobener's phenomenon and the pin point bleeding on removal of scale.

4. History or previous attack or seasonal relapse.

\section{INVESTIGATION}

Complete Blood Picture, Erythrocyte sedimentation rate, , Lipid profile, Liver Function Test, Random Blood Sugar, Renal Function Test, Ultra Sonography (whole abdomen \& pelvis), Chest X-ray(PA view), Electro cardio gram

\section{ASSESSMENT CRITERIA}

- Each sign and symptom is graded and a numerical value is given for assessment of results. The change and relief in symptoms was observed on completion of treatment.

- Overall effect of the therapy will be graded as follows:

\begin{tabular}{|l|l|}
\hline Complete remission & $100 \%$ relief \\
\hline Marked improvement & $75 \%$ to $<100 \%$ relief \\
\hline Moderate improvement & $50 \%$ to $<75 \%$ relief \\
\hline Mild improvement & $25 \%$ to $<50 \%$ relief \\
\hline No improvement & $<25 \%$ relief \\
\hline
\end{tabular}

No improvement

\section{- Clinical parameters:}

Table no.-2

\begin{tabular}{|l|l|c|l|}
\hline $\begin{array}{l}\text { S. } \\
\text { No. }\end{array}$ & $\begin{array}{l}\text { SIGN \& } \\
\text { SYMPTOMS }\end{array}$ & PARAMETERS & GRADE \\
\hline 1. & $\begin{array}{l}\text { Kandu } \\
\text { Itching })\end{array}$ & No Kandu & 0 \\
\hline
\end{tabular}

\begin{tabular}{|c|c|c|c|}
\hline & & Occasional & 1 \\
\hline & & $\begin{array}{l}\text { Off \& on without disturbed } \\
\text { sleep }\end{array}$ & 2 \\
\hline & & Continuous with disturbed sleep & 3 \\
\hline \multirow[t]{4}{*}{2.} & Matsyashakal & Normal skin & 0 \\
\hline & (Scaling) & Scaling on vigorous rubbing & 1 \\
\hline & & Scaling on light pressure & 2 \\
\hline & & Scaling on wearing cloth & 3 \\
\hline \multirow[t]{4}{*}{3.} & Aswedanam & Sweating & 0 \\
\hline & (Anhydrosis) & Mild sweating & 1 \\
\hline & & Mild sweating after exercise & 2 \\
\hline & & No sweating after exercise & 3 \\
\hline \multirow[t]{6}{*}{4.} & $\begin{array}{l}\text { Mahavastu } \\
\text { (Lesion on }\end{array}$ & No lesion & 0 \\
\hline & body parts) & of Lesion on partial (upto $2 / 3^{\text {rd }}$ ) part & 1 \\
\hline & & $\begin{array}{l}\text { Hand/Leg/Neck/Scalp/Ear } \\
\text { lobule/Back }\end{array}$ & \\
\hline & & $\begin{array}{l}\text { Lesion on partial (upto } 1 / 3^{\text {rd }} \text { ) part } \\
\text { of }\end{array}$ & 2 \\
\hline & & $\begin{array}{l}\text { Hand/Leg/Neck/Scalp/Ear } \\
\text { lobule/Back }\end{array}$ & \\
\hline & & - $\quad$ Lesion on whole body & 3 \\
\hline \multirow[t]{4}{*}{5.} & Erythema & . $\quad$ Normal skin color & 0 \\
\hline & & . $\quad$ Faint \& near to skin color & 1 \\
\hline & & . $\quad$ Blanching+ red color & 2 \\
\hline & & . $\quad$ Total red color & 3 \\
\hline \multirow[t]{2}{*}{6.} & $\begin{array}{l}\text { Candle Grease } \\
\text { Sign }\end{array}$ & Absent & 0 \\
\hline & & . $\quad$ Present & 1 \\
\hline \multirow[t]{2}{*}{7.} & $\begin{array}{l}\text { Koebner } \\
\text { Phenomena }\end{array}$ & Absent & 0 \\
\hline & & . $\quad$ Present & 1 \\
\hline
\end{tabular}

\section{STATISTICALANALYSIS}

Statistical analysis was carried out by using Wilcoxon Sign Rank Test. The result were interpreted at $\mathrm{P}<0.05, \mathrm{P}<0.01, \mathrm{P}<0.001$ as level of significance.

RESULT Table no.-3

\begin{tabular}{|c|c|c|c|c|c|c|c|c|c|c|c|c|}
\hline \multicolumn{3}{|c|}{ Patient } & \multirow[t]{2}{*}{$\mathbf{W} / \mathbf{T}+$} & \multirow[t]{2}{*}{ T- } & \multicolumn{2}{|c|}{ Mean } & \multirow[t]{2}{*}{ MD } & \multirow[t]{2}{*}{ \%Relief } & \multirow[t]{2}{*}{ SD } & \multirow[t]{2}{*}{ SE } & \multirow[t]{2}{*}{ P-value } & \multirow[t]{2}{*}{ Significance } \\
\hline S.NO. & Sex & Age (in year) & & & BT & AT & & & & & & \\
\hline 1. & $\mathrm{~F}$ & 31 & 21 & 0 & 2.0 & 0.57 & 1.42 & $71.00 \%$ & 0.78 & 0.29 & 0.0313 & Significant \\
\hline 2. & $\mathrm{~F}$ & 25 & 21 & 0 & 2.0 & 0.71 & 1.28 & $64.00 \%$ & 0.95 & 0.35 & 0.0313 & Significant \\
\hline 3. & $\mathrm{M}$ & 40 & 21 & 0 & 2.0 & 1.14 & 0.85 & $42.50 \%$ & 0.37 & 0.14 & 0.0313 & Significant \\
\hline 4. & $\mathrm{M}$ & 38 & 21 & 0 & 1.71 & 0.57 & 1.14 & $66.66 \%$ & 0.89 & 0.34 & 0.0313 & Significant \\
\hline 5. & $\mathrm{M}$ & 24 & 28 & 0 & 1.71 & 0.14 & 1.57 & $91.81 \%$ & 0.78 & 0.29 & 0.0156 & Significant \\
\hline
\end{tabular}

AT: After Treatment, BT: Before Treatment, MD: Mean Difference, SD: Standard Deviation, SE: Standard Error

\section{OBSERVATION}

\section{Table no.-4}

\begin{tabular}{|l|l|l|l|}
\hline S. No. & Overall assessment & No. of Patients & Percentage \\
\hline 1. & Complete remission & 00 & $0 \%$ \\
\hline 2. & Marked improvement & 01 & $20 \%$ \\
\hline 3. & Moderate improvement & 03 & $60 \%$ \\
\hline 4. & Mild improvement & 01 & $20 \%$ \\
\hline 5. & No improvement & 00 & $0 \%$ \\
\hline
\end{tabular}

\section{DISCUSSION}

Psoriasis is a chronic inflammatory disease, in chronic diseases there are severe vitiation of channels (Srotodushti), weakness of digestive fire (Agnimandya), improper nourishment of tissues and decreased immunity (Ojokshaya), which warrants the purification of body, for this bio-purification Virechana Karma (therapeutic purgation) is indicated in skin disorders. At first the body should be prepared with Pachana and Deepana Karma (for Amapachana), the Dosha, which are present in Dhatu and Srotasa are moistened by Snehana (internal oleation), liquified by Swedana (fomentation) and then brought to Koshta (stomach), thereafter it should be expelled by Shodhana (biopurification). ${ }^{5}$ The hot, sharp, penetrating, prevailing and loosening drugs of Virechana Yoga (Trivattadi Kwath and Icchabhedi Rasa) because of their potency reaching the heart and circulating through vessels effect the mass of impurity in the entire body, liquify it out through large and small ducts due to its fiery nature and disjoin it due to sharpness, consequently the disjoined mass floating in the uncted body like honey in uncted vessel, reaches the stomach due to penetrating nature, composition of Virechana drug predominates in Jala (water) and Prathivi (earth) Mahabhuta and there is specific potency (for purgation), it goes down. ${ }^{6}$ According to modern view laxative probably induce limited mild inflammation in the small and lower bowel, which facilitates quick absorption of the active principles (Virya) of the drug in initial stage. Later on it facilitate the excretion of the morbid matters, which generally are not supposed to be excreted out through the mucosa of gut. It is possible only because inflammation increases the permeability of the capillaries, which in turn allow the absorption, as well as excretion of such substances which are not allowed in normal condition. $^{7}$ The effect of Virechana Karma was observed that, complete cure was not in any patient. One patient was mild improved, one patient was markedly improved and three patients were moderately improved. None of patients remained unchanged.

\section{CONCLUSION}

On the basis of this clinical trial, it can be concluded that Virechana Karma works effectively in the management of psoriasis. This Ayurvedic modality helps to prevent the progression of disease. This research paper highlighted the role of Virechana Karma in psoriasis. This clinical trial was carried out on only 5 patients, for further research large number of sample size is necessary. 
1) H Ralston Stuart, D Penman Ian, et. Al., Davidson's Principles and Practice of Medicine, 23rd edition 2018, Ch. 29, Page no. 1212 and 1247-1248.

2) Shastri Kashinath \& Chaturvedi Gourakha Nath, edited Charak Samhita of Agnivesh, revised by Charak and Dridhbala, Part-2,Chaukhambha Sanskrit Sansthan, Varanasi Reprint 2017; Chikitsasthana 7, verse 86-87, page no. 152 .

3) Gupta Atrideva, edited by Upadhyaya Yadunandana, Ashtangahridayam of Vagbhatta, Chaukhambha Prakashan, Varanasi Reprint 2010; Nidanasthana 14, verse 3.

4) Clinical Research Protocol for traditional health sciences, Central Council for Research in Ayurveda \& Siddha, New Delhi, 2009, Page no. 918.

5) Gupta Atrideva, edited by Upadhyaya Yadunandana, Ashtangahridayam of Vagbhatta, Chaukhambha Prakashan, Varanasi Reprint 2010; Sutrasthana 17, verse 28-29, Page no. 274.

6) Shastri Kashinath \& Chaturvedi Gourakha Nath, edited Charak Samhita of Agnivesh, revised by Charak and Dridhbala, Part-2,Chaukhambha Sanskrit Sansthan, Varanasi Reprint 2017; Kalpasthana 1, verse 5, Page no.891.

7) Patil Vasant C., Text book of Panchkarma Vijnana, Chaukhambha Publications New Delhi, Reprint 2018; Chp. 5, Page no. 262 